UDC 159.942.5-056.262

DOI: 10.52534/msu-pp.7(4).2021.66-75

\author{
Liudmyla A. Varava ${ }^{1}$, Olena V. Kochetova ${ }^{1^{*}}$, Victor Orest ${ }^{2}$ \\ ${ }^{1}$ Mariupol State University \\ 87500, 129a Budivelnykiv Ave., Mariupol, Ukraine \\ ${ }^{2}$ National Taipei University \\ 10478, 67 Sec. 3, Ming Shen East Road, Taipei, Taiwan
}

\title{
Structural Components of Personal Well-Being Experience of Persons with Functional Visual Disorders
}

\author{
Article's History: \\ Received: 21.09.2021 \\ Revised: 20.10 .2021 \\ Accepted: 22.11.2021
}

\section{Suggested Citation:}

Varava, L.A., Kochetova, O.V., \& Orest, V. (2021). Structural components of personal well-being experience of persons with functional visual disorders. Scientific Bulletin of Mukachevo State University. Series "Pedagogy and Psychology", 7(4), 66-75.

*Corresponding author

\begin{abstract}
The problem of experiencing personal well-being as a question of positive functioning of the individual in the actualised areas of life is relevant for modern psychological science and practice. The purpose of the study was to determine the supporting components of the experience of personal wellbeing of persons with functional visual impairments, the level of severity of which mediates such experiences. The study is based on determining the leading role of internal determinants in the experience of personal wellbeing in the conditions of functional visual impairment. As a result of the research, a structural model of experiencing well-being of persons with functional impairments is outlined, which includes such components as self-attitude (positive or negative) and experiences of personal capabilities or limitations in actualised ego identities. The study determined that the low degree of expressiveness of the modalities of self-assessment and the negative colour of personal experiences of functional disorders prevent the realisation of person's resourcefulness, the actualisation of its capabilities. Empirical research has shown that distorted self-perception of people with functional visual impairments is mediated by rigidity of self-image, its closedness, and personal experiences of limitations in relation to their own functional disorders in actualised spheres of life. The identified features of the structural components of experiencing their own well-being can be used to develop and implement a correctional programme aimed at forming an adequate level of self-esteem in persons with functional impairments, which confirms the practical significance of the study
\end{abstract}

Keywords: well-being of the individual, experience of well-being, self-attitude, self-concept, ego-identity, personal capabilities, functional and personal limitations

\section{INTRODUCTION}

The issue of a well-being of individual is currently relevant not only for modern psychological science and practice, but also for the further comprehensive development of the state. Experiencing personal well-being and happiness is one of the leading conditions for the full functioning of the individual in society, it acts as a condition and consequence of meeting one of the basic human needs - the need for self-realisation, a sense of subjectivity. The definition and investigation of certain components of experiences allow the study to come closer to understanding those aspects of the existence of the individual that ensure its successful existence in specific conditions and circumstances. In conditions of functional impairment, in particular visual impairment, the mechanism of experiencing personal well-being is based on general patterns, but it may acquire certain features conditioned by the specifics of internal factors that determine the experience of personal well-being.

Thus, O.V. Huliaieva found that the experience of well-being by persons with functional disorders is characterised by internal contradictions: a positive emotional background (emotional well-being) is combined with low life satisfaction and low level of positive functioning (psychological 
well-being) [1]. According to the study by Yu.M. Shvalb and L.V. Tishchenko, it was determined that most of the investigated persons with functional disorders have a low level of awareness of life, perceive their own life as uninteresting and emotionally insatiable, unfilled with meaning [2]. They experience their own life as unrealised, pointing out the absurdity of its previous stage. These components determine the content of the existence of the subject, the internal measure, the criterion and regulator of which, in fact, is the experience of well-being of the individual. At the same time O.V. Huliaieva identified a specific source of experiencing subjective (emotional) distress by students with functional disorders [1]. It is an assessment of their own health: emotional colouring, the meaning of life is perceived by people with functional disorders through their own functional state, through their own functional disorders, conditioned by limitations. The importance of an adequate attitude to their own functional impairment is noted by K.K. Sotnikova, who considered the self-acceptance of people with functional visual impairments in the context of psychological, social and professional adaptation [3]. The researcher emphasises the difficulties that arise in the process of establishing social ties and relationships. Substantiating the main methods and stages of work on psycho-social adaptation of persons with functional visual impairments, K.K. Sotnikova notes that the result of such adaptation is a sense of personal ego-identity, achievement and experience of psychological satisfaction in a new cultural environment, etc. [3].

Thus, despite the fact that the problem of prosperous "I" existence of people with disabilities is identified by Ukrainian researchers, the peculiarities of experiencing personal well-being of people with disabilities are rather underinvestigated. At the same time, in today's world there is a need: currently one of the strategic goals of the National Strategy for Creating a Barrier-Free Space until 2030 in Ukraine is to create the necessary conditions for self-realisation of people with limited mobility, including people with visual impairments [4]. The practical implementation of programmes and projects aimed at creating psychological conditions for self-realisation of persons with functional visual impairments in specific living conditions and circumstances, requires appropriate scientific and theoretical framework and methodological tools. Therefore, it is necessary to determine which internal determinants and certain conditions contribute to or prevent a person with visual impairments to adapt and lead a full life, to experience their own existence as prosperous. Functional disorders, in particular, disorders of the visual analyser, limitations in life, created by this disorder, are contained not in the disorder itself, but in the consequences, those secondary deviations that are caused by the disorder. However, in case of vision loss, a person is still able to adequately perceive and imagine the surrounding reality and themself in it by activating compensatory reserves.

The purpose of the study is to identify and describe the structural components of experiencing personal well-being of persons with visual impairments. Therefore, it can be noted that the objectives of the study are: to clarify the peculiarities of experiencing well-being of persons with visual impairments; identification of the main structural components, the degree of severity of which affects the experience of well-being of persons with functional impairments.

\section{LITERATURE REVIEW}

There is no single common definition of psychological wellbeing in modern psychology. As noted by N.V. Volynets [5], this phenomenon is considered by researchers as a multilevel multifactorial psychological construct that covers all aspects of positive personal experiences in the process of assessing quality of life, inner satisfaction with life in general. Thus, L.V. Karapetyan, G.A. Glotova proposed a concept "emotional and personal well-being", which allows integrating the idea of subjective (emotional, hedonistic) and personal (psychological, eudemonistic) well-being, understood by researchers as a holistic existential experience of harmony between the inner and outer world. It occurs in the process of life, activity, and communication of a person. Thus, according to the authors, personal (psychological) well-being is an integral part of a more voluminous construct - emotional and personal well-being. Researchers N.A. Baturin, S.A. Bashkatov, N.V. Gafarova consider it necessary to introduce the term "personal well-being" to denote a phenomenon of a more general nature than psychological and subjective well-being [7]. The researchers define personal well-being as a systemic formation of the human psyche, based on positive functioning, which allows being positive in various areas of life, and on the other hand, the presence of positive subjective assessments of external factors of well-being. Subjective well-being is a generalised reflection of factors at all levels in the form of emotions, evaluations, and judgments that allow a person to feel satisfied with life.

At the same time O.V. Huliaieva in her study applied a comprehensive approach, i.e., an integrated model that combines hedonistic and eudemonistic views on the psychological well-being of person [1]. This approach identifies three components of psychological well-being: emotional, cognitive, and behavioural. The emotional component of psychological well-being reflects the positive or negative attitude of the individual that arises during the implementation of goals. Cognitive component of psychological wellbeing involves the assessment of the person's life and life satisfaction in general. Behavioural component of psychological well-being consists of resources that ensure the positive functioning of the individual and their self-realisation. A.V. Voronina [8] also suggested her own approach to the problem of experiencing psychological well-being. This approach is based on the idea that genetic factors may also explain individual differences in the experience of psychological well-being.

A.V. Voronina proved that different levels of psychological well-being can be explained by quantitative and qualitative differences in individual and personal characteristics [8]. The researcher defines psychological well-being as the inner intentions of man (unconscious and conscious 
resource guidelines for viability, self-development, self-expression, and self-realisation), which are implemented in the process of activities that are resources of psychological well-being. N.V. Volynets substantiates the system-holistic approach to the study of personal well-being, which allows establishing a connection between the characteristics of the individual and the peculiarities of experiencing the space of life [9]. According to the definition, psychological well-being is considered as a generalised, integral, reflected indicator of a person's experience of quality of life in all actualised spheres of life, and an assessment of personal quality of life in general. Its main feature is subjectivity, it is productive, holistic, and comprehensive.

According to S.O. Minyurova and I.V. Zausenko, the achievement of psychological well-being requires certain efforts from a person: active systematic work on themselves, development of such personal qualities that allow maintaining the stability of positive functioning in relevant areas of life [10]. Psychological well-being of the individual, according to the researchers, is the experience of satisfaction with own life as a result of positive functioning, which was achieved through self-development. Personal qualities are determinants of personal well-being. The reseaerchers consider personal qualities in the continuum of motivating and stabilising [10]. At the same time, low indicators of psychological well-being are associated with the fixation of the individuals on their own weaknesses.

On the level of implementation of environmentallyoriented human activities, Yu.M. Shvalb [11] points to the close connection between environmental values (as a kind of values that cover the sphere of interaction in the system "human-nature") and the emotional sphere of man. Since the values of the individual as meaning-making units of consciousness are assimilated and developed based on positive emotions, environmental values are included in the emotional and value sphere of personality and determine the intensity and course of human behaviour in relevant areas of life. According to the researcher, it is the emotional assessment of a person's own life as a whole reflects the general level of their psychological well-being and probably determines the ecological orientation of human life [11]. Thus, ecological orientation of human life, reflected in the emotional and value attitude of a person to themself, to the social and natural environment, reflects the general level of their psychological well-being and determines the successful functioning of the individual and their life in general.

Considering the phenomenon of experience, M.V. Papucha [12] points to its important role. According to the researcher, it contributes to the awareness of the attitude of the individual to the events of their own life, i.e. "aimed at establishing a semantic correspondence between human consciousness and its existence" [12]. At the same time, if according to N.V. Volynets, the experience of psychological well-being by a person is an internal reflection of a prosperous self-existence [13], a persistent emotional experience of the futility of own existence can be defined as social deprivation and stigmatisation, and may indicate personal distress. This can occur in conditions of functional visual impairment. Then the negative experience is a consequence of the destruction of hopes for the realisation of their own capabilities, reduced motivation to succeed and achieve goals, loss of life prospects, etc. N.V. Volynets emphasises the productive essence of experiencing psychological well-being, as it can change perceptions, views, attitudes, values, and the products of experiencing psychological well-being are mental balance, new values, meaningfulness, completeness, integrity of life [13].

Modern psychological studies of self-esteem are based on different approaches to determining the phenomenon of human attitude to themself. A.M. Kolyishko identifies three independent approaches to understanding the phenomenon of personality self-attitude: self-attitude in the personality structure (as a trait), self-attitude as a component of self-regulation, and self-attitude as a structural component of self-awareness (emotional and value, affective component) [14]. The most promising in modern psychology is the approach according to which self-attitude is a direct presentation in the human mind of the personal meaning of the self, i.e. the approach according to which self-attitude is considered as a component of self-consciousness [15]. The basic in this case is the idea of V.V. Stolin that the foundation of self-assessment is the assessment of the individual's own self, own traits and properties in relation to their own motives, which express the need for self-realisation [16]. The personal meaning of the Self is manifested in the fact that the individual considers their own self, their own characteristics, opportunities, properties as a condition for self-realisation, that is, a person comprehends themself as a condition for achieving their own goals. V.V. Stolin notes that personality traits can be conditions that either contribute to the achievement of the goal, or are an obstacle to the implementation of their own motives [16]. Then, in the first case, the personal meaning of the Self will be positive (I-condition that promotes self-realisation), and in the second case - negative (I-condition that prevents self-realisation). Self-assessment of personality as a component of self-awareness that performs the function of human acceptance of self, awareness of their own characteristics, capabilities and limitations, is studied in conjunction with the self-concept of personality, its cognitive descriptive component. The self-image of the individual meaningfully characterises the role repertoire of the individual, their ego-identity in certain areas of their life, i.e. is a role identity (due to the social roles of the individual).

Due to the systematisation of scientific approaches, O.O. Podzhynska defines personal identity as a person's self-determination in terms of physical, intellectual, and moral traits, where the key is the value and volitional aspect, which is expressed in the choice of goals, values that a person follows throughout life [17]. The researcher emphasises the importance of forming a value component of personal self-consciousness, because it is values that serve as life landmarks that guide the choice of leading activities, determine the hierarchy, subordination of motives, give personal meaning, 
i.e. guide and shape the personality. They are the basis of personality, which ensures the integrity of its development, its identity. Yu.M. Shvalb notes that the individual's solution to the problem of self-identity allows them to choose their own life motives, to gain independence from the challenges of life circumstances [11]. The researcher considers the process of identity establishment in the context of the development of psychological abilities of the individual, which allow them to be the subject of activities and their own life relationships, allow not only engaging in specific activities, but creating and organising them. The development of these abilities is carried out as a result of solving a special type of tasks in such spheres of life as social relations (socialisation process), the sphere of cultural values and meanings (personalisation process), and the sphere of individual existence (individualisation process).

\section{MATERIALS AND METHODS}

An empirical study aimed at determining the structural components of experiencing the well-being of people with visual impairments involved 60 respondents aged 35 to 50, with the first and second disability groups, who are members of the Mariupol Territorial Primary Organisation of the Ukrainian Society of the Blind. Criteria for selection of respondents were: mature age (35-50 years) and disability group (first and second). Given the predominantly low social activity of people with visual impairments, secrecy and isolation of such people, personal readiness for self-disclosure is also a criterion for selecting respondents.

The selection of tools and the procedure of empirical research was carried out taking into account the characteristics and capabilities of respondents: test questions were voiced (if necessary) by the researcher to the respondent; This procedure of empirical research acquires a certain specificity, as it loses anonymity and, compared to the standard procedure, requires much more time and certain skills of the experimenter. At the same time, such a procedure allowed the participation in the study of persons with profound functional visual impairments who do not have the skills of non-visual work on the PC, which increased the representativeness of the sample.

To determine the characteristics of experiencing their own well-being of persons with functional visual impairments at the first stage was used standardised method "Scales of psychological well-being by K. Ryff" in the version of T.D. Shevelenkova and T.P. Fesenko [18], which determined the level of integrated indicator of psychological well-being of respondents and the degree of expression of its main components, namely: self-acceptance - a component that reflects a positive assessment of themselves and their lives in general, awareness and acceptance of their positive qualities and shortcomings; positive relationships with others as the ability to empathise, and openness to communication, as the ability to establish and maintain contacts with other people, to be flexible, to be able to compromise; autonomy testifies to a person's ability to have their own opinion, to be independent of the opinion of others, to act and evaluate themself based on their own preferences; environmental management indicates the presence of qualities that determine the successful mastery of various human activities: the ability to achieve the desired goal, overcome difficulties, etc. The presence of life goals gives a sense of meaningful existence, the value of the past, present, future prospects; personal growth includes the desire for development, the focus on learning and perception of the new, the presence of a sense of progress. High, medium, and low levels of expression of components and the degree of expression of the integrated indicator of psychological well-being of respondents are determined according to the instructions: raw scores are translated into the scores, which, according to the figure, correspond to a certain level of expression, etc.

The second stage of the study included the method "Test-questionnaire to determine the self-assessment of personality (V.V. Stolin, S.R. Pantileev)" [19] to investigate the peculiarities of self-assessment of persons with functional visual impairments. According to the authors, self-attitude as a stable feeling towards own self contains a number of specific modalities or dimensions: inner honesty, self-confidence, self-management, self-worth, self-acceptance, selfattachment, inner conflict, and self-blame, which differ emotionally, experience, and the semantic content of the corresponding attitude to themselves.

The phenomenon of the experience of persons with functional visual impairments about their own capabilities and limitations in current ego-identities was studied using the projective methodology by M. Kuhn, T. McParkland "Who I am" [20], which aims to investigate the substantive characteristics of identity. The answer to the question "Who am I?" directly related to the self-perception of the person, with the definition of their own social roles and psychological characteristics, i.e., awareness of their own self-image, which is an indicator of the actualised spheres of life of the individual. Since the authors determined that the number of answers should be at least twenty, the inability of the respondent to determine their own ego-identities in the required number of answers may indicate a lack of personal reflection or impoverished role repertoire, narrowing of spheres of life and work. Content-processing of answers also allows analysing the presence in the structure of the self-image of the subjects of the fact of defects and limitations, as evidenced by answers such as "I am disabled" or "I am inferior", etc. The methodology consists of two stages. In the first, the respondent gives a number of answers to the question "Who am I?", which are recorded independently or by the researcher (if necessary). In the second stage, personal experiences of opportunities or limitations in relation to each ego-identity indicated by the respondent are actualised in the respondents by choosing the answer to the researcher's question: "How do you experience your own functional visual impairment?": a) full restriction; b) partial restriction; c) I do not know; d) partial opportunities; e) full opportunities. Determination of the percentage comparison of each respondent's personal experiences in relation to opportunities and limitations in the ego-identity 
allows finding out whether the respondent's self-actualisation predominantly occurs through opportunities or limitations, how positive or negative is the personal meaning of the self (according to V.V. Stolin [16]) in this case. This tool can also be used to determine those ego-identities in which personal experiences are on the continuum "partly possible, quite possible" to use them as basic ones in further remedial work with the self-image of a person.

\section{RESULTS AND DISCUSSION}

\section{Features of experiencing personal well-being by people with functional impairments}

Theoretical analysis of modern approaches to the study of the experience of personal well-being and self-assessment of the individual as an emotional and value component of self-awareness allowed outlining a plan of empirical research $[21 ; 22]$. Therefore, according to the results of the first stage, it can be stated that most subjects (85\%) showed a medium level of psychological well-being, 5\% - high, and
$10 \%$ - low levels of the integrated indicator of psychological well-being. 95\% of respondents demonstrate an average level of meaningfulness of life, the presence of interactions that give meaning to life. Among the participants in the survey, $75 \%$ are open to gaining new experience, tend to use opportunities to develop their own potential. On the other hand, $20 \%$ acknowledge the lack of their own development, do not feel improvement or self-realisation, as evidenced by the low level on the scale of personal growth. It is noteworthy that some of the subjects have differences between the level of expression of the integrated indicator of psychological well-being (average) and the low level of expression of components that have personally significant assessments. This is ambiguous. Thus, against the background of the average level of satisfaction with the quality of own life $(85 \%$ of respondents), $45 \%$ of respondents show a low level of self-acceptance, which indicates a persistent negative experience of dissatisfaction with themselves, their situation, frustration with their past, etc. A more detailed description of the survey results is shown in Figure 1.

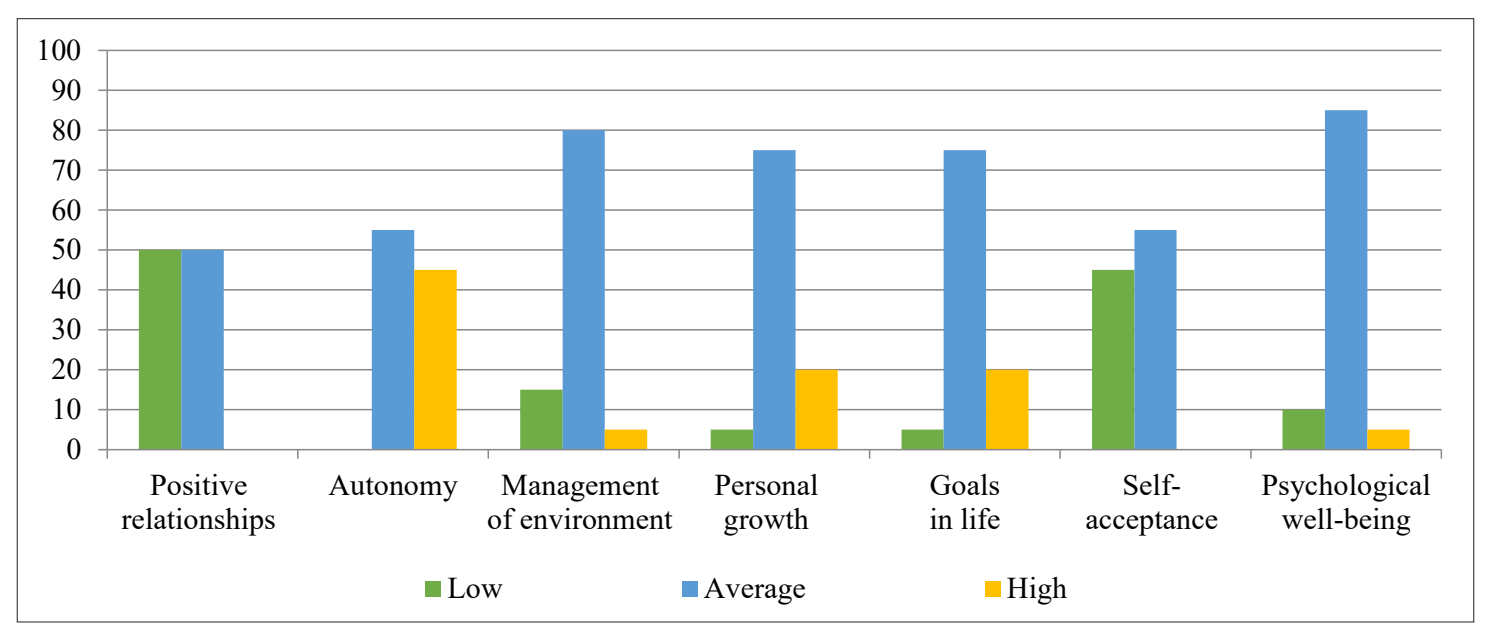

Figure 1. Level of expression of the integrated indicator of psychological well-being and its components in the subjects (\%)

Negative tendencies in self-acceptance are based, first of all, on insecurity in own strengths and abilities, which leads to high emotional anxiety. Without a positive understanding of the possibilities of their own lives, the experience of positive functioning, people with functional impairments get used to their own maladaptive thoughts, learn to live with negative feelings about their own functional limitations and lack of opportunities [23]. There is an establishment of a sense of learned helplessness, which is characterised by difficulties with self-identification and, as a consequence, with self-acceptance. Thoughts about the future are confronted with negative perceptions of themselves and, in turn, determine the nature of perceptions of their own capabilities. There is a kind of vicious circle. Distorted self-perception, based on awareness of their own limitations and accepting such awareness as a constant affects the increased sensitivity to environmental assessments, leads to distortions in the communicative sphere, violations of interpersonal relationships, isolation from the environment. This is confirmed by the results: a sufficient level of positive, every second respondent has warm relationships with people, while $50 \%$ have only a limited number of trusting relationships, they find it difficult to be open, they are isolated and frustrated, in interpersonal relationships tend to take the position of a bystander.

The primary reason for the lack of behavioural skills in society, the loss of initiative in communication may be the lack of non-verbal communication, which occurs due to functional impairment of the visual analyser. Vague perception of the expression of the interlocutor's face or the impossibility of such perception, leads to misunderstandings and communication barriers, does not allow a person to obtain reliable information about the attitude of others. Against the background of habitual thoughts about own limitations, the situation of lack of positive relationships with other people may no longer cause acute negative feelings, it 
also becomes habitual and ordinary and only confirms for a person the fact of their limitations, increasing the state of forced helplessness. The average level of expression of the component on the scale of autonomy is currently $55 \%$ of people with visual impairments, among those who participated in the survey, indicating the advantage of their independence and independence, the ability to assess themselves based on their own standards. Respondents with a high level of autonomy (45\%) demonstrate independence from the assessment and opinion of others, focusing on their own goals and desires. However, against the background of low and medium indicators of self-acceptance and positive relationships with others, such a distribution of high and medium scores on the scale of autonomy may confirm the tendency of some respondents to isolate themselves from fear of rejection. It can also be a sign of loneliness of some respondents, their social isolation, etc.

High indicators of expressiveness on the scale of autonomy can be interpreted as a sign of a positive trend that has recently been observed in society. The state's focus on inclusion in communities expands the interactive capabilities of people with visual impairments, gradually generates thoughts and actions towards self-development, stimulates a person to personal growth, encourages them to find ways of their own independence. This opinion is confirmed by the average score indicators on the scale of meaningfulness of life and personal growth.

The mental development of a person with visual impairment in conditions of reduced activity caused by functional disorders of the perceptual sphere is closely related to social adaptation, which requires special patterns of adaptation to the world. The isolation of a person with functional visual impairments relative to generalised others against the background of increasing external opportunities for self-realisation turns into a shift of man towards forced independence in the usual "safe" microsociety, consisting of people with functional impairments. Creating a family and having children, caring for elderly relatives encourages independence, personal growth, a sense of subjectivity, and the progress in person's life. Successful mastery of a person's various activities, the ability to overcome the difficulties that arise, cause positive functioning and provide a sense of experiencing their own life as a prosperous one. However, against the background of the unformed ability to integrate the experience gained in the micro-society into relevant areas of life, there is a fragmentary, unrealistic perception of various manifestations of life, so personal experience of well-being acquires certain features.

Thus, at the first stage of study it was found that in the structure of experiencing well-being of persons with functional impairments there are components that prevent the establishment of resourcefulness of the individual and the actualisation of its capabilities. Respondents have a positive experience of their own life as a prosperous life in the case of fixation on those components of life that are experienced in the context of personal capabilities.

\section{Features of self-assessment of persons with functional visual impairments}

The second stage of the study was aimed at determining the dimensions and modalities that give respondents a certain specificity. Admittedly, the mechanisms of forming an individual's attitude to themselves are based on a system of ideas about their own characteristics, capabilities, and limitations. In conditions of functional visual impairment, the pattern of adaptation to the surrounding reality may be based on protective mechanisms such as displacement or denial. According to the survey, $60 \%$ of respondents showed high scores on the scale of internal honesty. They are mostly not open with other people, have difficulty understanding important aspects of self-attitude, behaviour, etc. Indicators on the openness scale correlate with indicators on the measurement of internal conflict, namely: 55\% of low-score participants show a tendency to deny problems, superficiality in assessing their self-esteem, which may indicate rigidity of self-image and projected into socially desirable in their answers. So far, none of the subjects has shown the result of dissatisfaction with their own capabilities, poor self-regulation, blurred locus of self, etc. High and medium (20\% and $80 \%$, respectively) scores on the scale of self-confidence, determined from the answers of the respondents, indicate the desire of respondents to demonstrate themselves as independent, strong-willed, and reliable individuals.

Emphasis on their own subjectivity, on the understanding that they themselves create their own reality, was made by $40 \%$ of people with functional visual impairments among the subjects. At the same time, $60 \%$ of other respondents showed that in most cases they also see themselves as the main source of activity, such that they are able to take responsibility for the results of their own activities if necessary. In this context, functional visual impairments cause disorders in the processes of identification and self-actualisation. This is conditioned by inadequate attitude to own functional impairment, tendency to ignore the fact of visual impairment and its consequences or its hyperbolisation: the person's assessment of the world around them, social relationships, and themself reflects the internal inconsistency of the individual. Since the experience of emotional and value attitude of the individual to themself does not depend on the comparison of successes and failures, autosympathy is not associated with the desire for a socially desirable image of person. The vast majority of respondents (80\%) showed average scores of emotional evaluation of themselves on the inner intimate criteria of love, spirituality, wealth of the inner world. They are also friendly to themselves, which is manifested in the overwhelming approval of their own plans and desires, which is a sign of adaptability. High scores on the scale of self-worth indicate the experience of feeling the emotional value of the subjects in relation to their own personality and at the same time express the idea of the value of their own self for others. Indicators such as $20 \%$ of respondents with high scores and $65 \%$ with medium scores on the scale of self-reflection (ego-alter) correspond 
to respondents' perceptions that their appearance, character, and activities can evoke sympathy, respect, and understanding of the generalised other. However, according to the results of the first phase of the study, such expectations may be the result of lack of sufficient experience of interpersonal relationships or the result of communication mostly only with people in a micro-society consisting of people with functional impairments. The expectation of a positive attitude towards oneself from the generalised other can also be an indicator of a change in the tendency to isolate oneself from society, as a manifestation of the expectation of recognising the fact that the world and society are able to positively perceive a person with functional disabilities and believe in their possibilities [24]. The results of the second stage of the survey are shown in Figure 2.

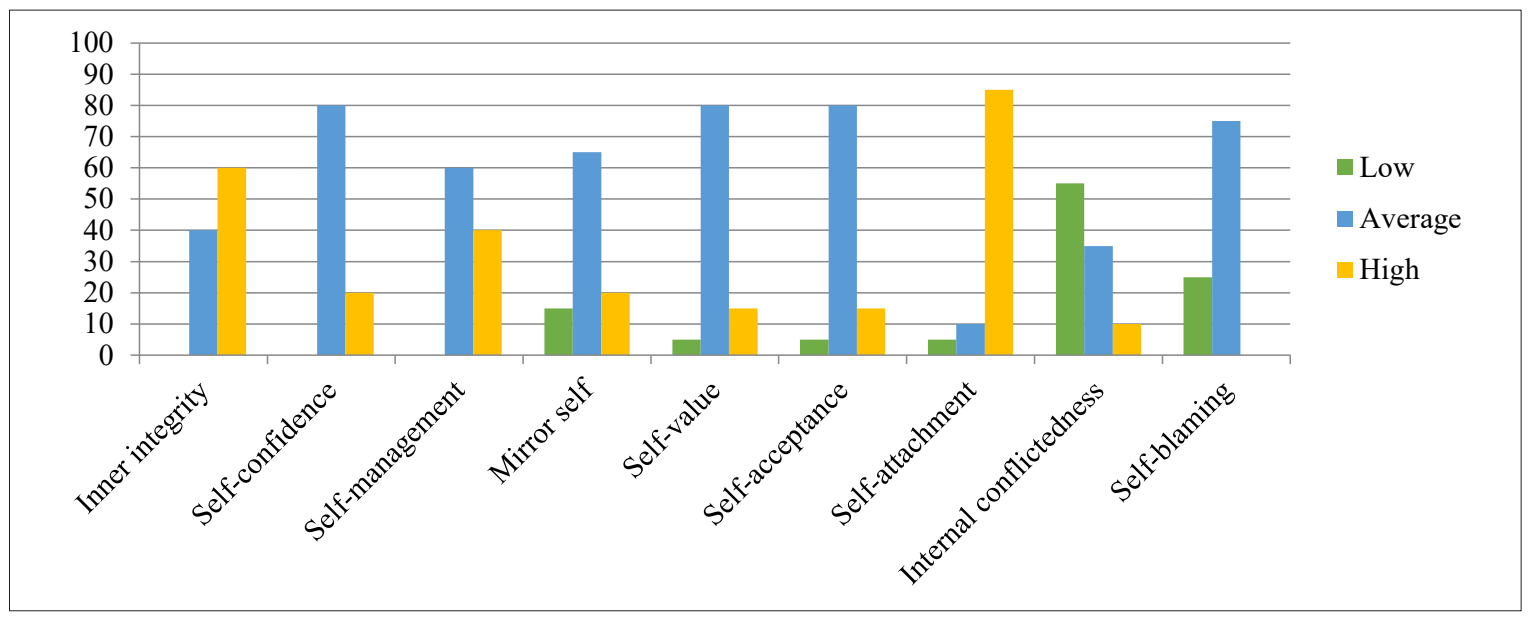

Figure 2. Level of expression of self-assessment modalities in the subjects (\%)

Thus, according to the results of the second stage of the survey, it was determined that difficulties in understanding important aspects of behaviour and self, closedness, tendency to deny problems significantly distorts the self-esteem of the individual; personal image turns into a closed rigid system of ideas about the individual. A high degree of autosympathy in the absence of sufficient experience of interpersonal relationships and protective mechanisms determine the specifics of self-identification of persons with functional impairment.

\section{Peculiarities of experiencing capabilities and limitations of persons with functional visual impairments}

The third stage of the study allowed analysing the presence of the fact of defects and limitations in the non-standardised self-description of the respondents. Determining the percentage comparison in each respondent's self-description of personal experiences in the actualised ego-identities in relation to opportunities and limitations in the study allows recording that in the case of experiences of physical limitations (fractional or complete), the person's centring on this fact results in the state of experience of psychological limitations as well [25]. Thus, when asked about their own experience of opportunities or limitations in ego-identities defined by respondents in the context of their own functional visual impairments, $90 \%$ of respondents identified their own experiences of most actualised social roles as "partially possible" or "completely possible". In the subjects with functional visual impairments, the feelings about the limitations (both partial and complete) in the structure of the self-image regarding the actualisation of certain ego-identities defined by the respondent are also actualised to varying degrees. They are available to each respondent in different percentages. The results are shown in Figure 3.

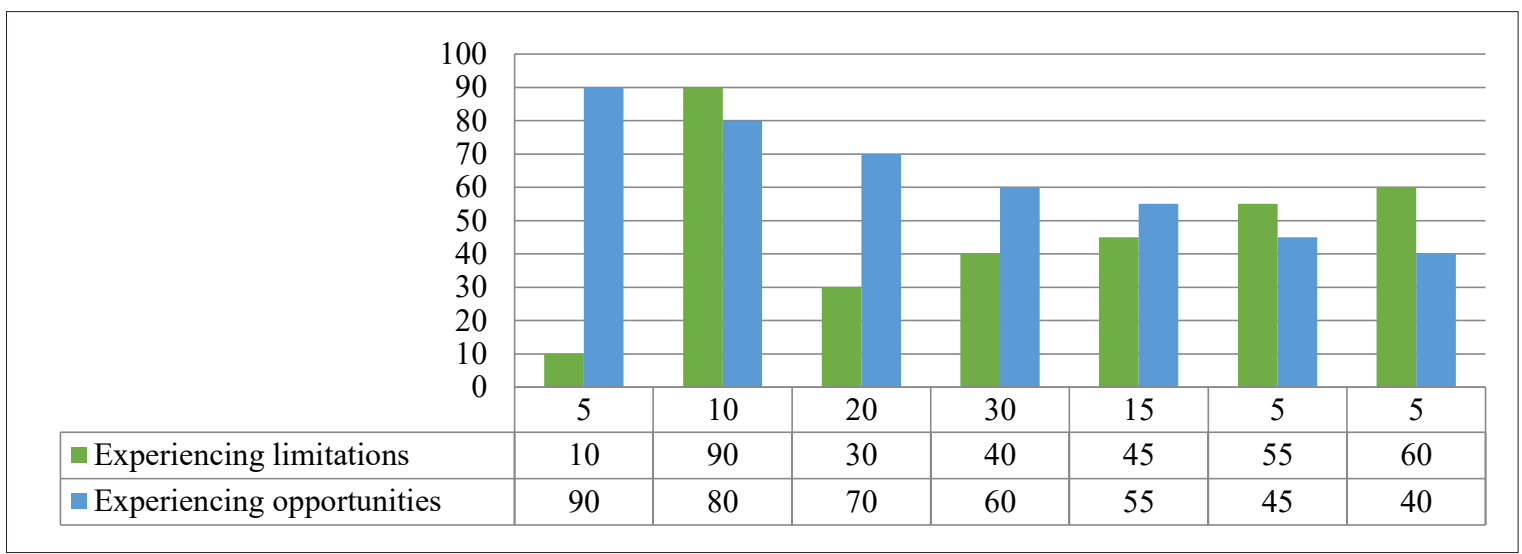

Figure 3. Comparison of personal experiences of opportunities and limitations explored in actualised ego-identities (\%) 
Thus, actualised ego-identities of persons with functional visual impairments may be experienced in the context of their own capabilities. The presence of the fact of limitation in the structure of the self-image provokes negative personal experiences, which hinders the proper functioning.

Thus, the study identified the structural components of experiencing personal well-being of individuals with functional impairments. Such structural components are self-attitude of the individual (positive or negative) and personal experiences of their own capabilities or limitations in the actualised ego-identities. This allowed creating a structural model of experiencing the well-being of people with functional impairments, which is shown in Figure 4.

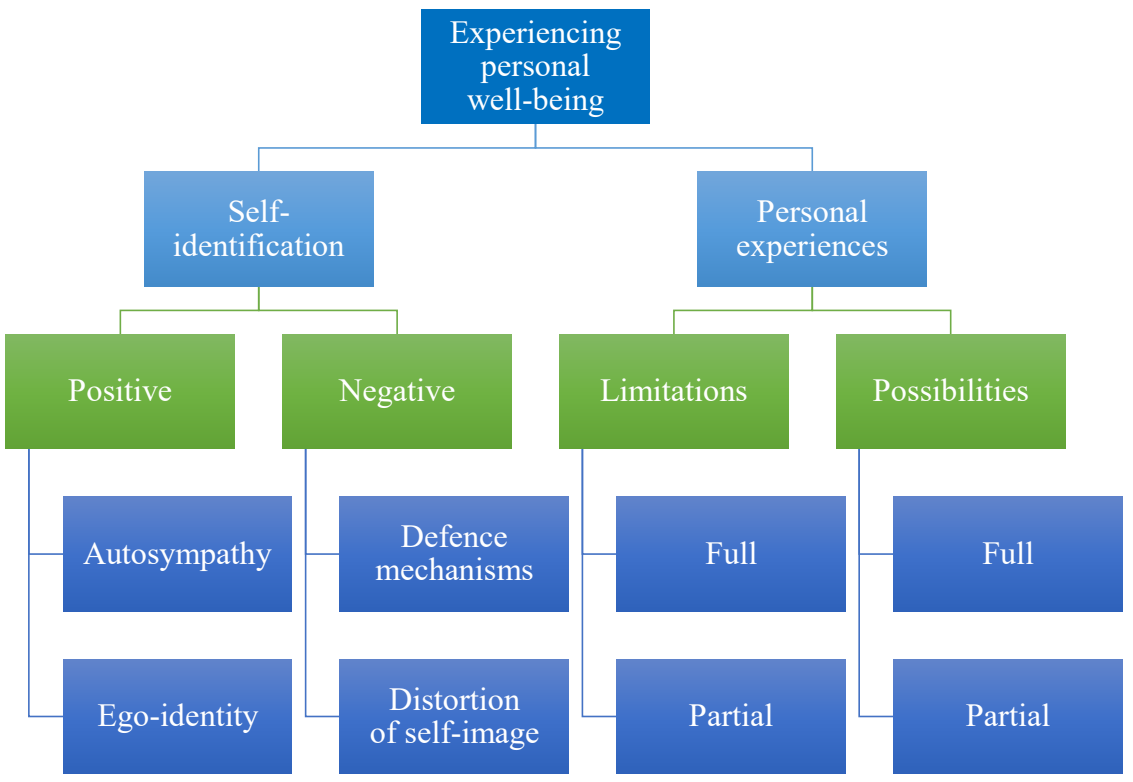

Figure 4. Structural components of experiencing personal well-being of individuals with functional impairments

The presented model clearly demonstrates which components are leading and supporting in the experience of personal well-being of persons with functional visual impairments. The structure outlined by the researchers can be the basis for the creation and implementation of a correctional training programme, which would provide for the establishment of positive self-esteem of persons with visual impairments. In the case of positive self-attitude (condition that promotes self-realisation), there is a mental state in the form of personal experiences of their own capabilities, which, in turn, reinforces the positive attitude of the person to themself.

\section{CONCLUSIONS}

Thus, the study found that the peculiarities of experiencing their own well-being of persons with visual impairments indicate differences between the level of expression of the integrated indicator of psychological well-being and the level of expression of components with personality-relevant assessments. It is confirmed that positive experiences of own life as a prosperous person with functional visual impairments occur due to the fixation of respondents on those factors and components of life that are experienced in the context of opportunities. It is determined that the structural components of experiencing their own well-being of persons with functional impairments are self-esteem (positive or negative) and personal feelings about their own capabilities and limitations in actualised spheres of life, realised through ego-identity. It was found that the influence of protective mechanisms, lack of sufficient experience of interpersonal relationships and a high level of autosympathy determine the specifics of self-identification of persons with functional visual impairments. It was found that the inclusion of the fact of limitation in the structure of the self-image leads to its distortion, complicating or slowing down the process of self-identification. At the same time, as a result of a person's focus on the fact of their own physical limitations (complete or partial) and experiencing such limitations, there is a state of psychological experience of complete or partial inability to function in actualised spheres of life.

Selected features that prevent people with visual impairments from experiencing full well-being need further development of a correctional programme and work to eliminate psychological barriers.

\section{REFERENCES}

[1] Huliaieva, O.V. (2018). Factors of psychological well-being in students with disabilities health opportunities (Candidate thesis, V.N. Karazin Kharkiv National University, Kharkiv, Ukraine).

[2] Shvalb, Yu.M., \& Tishchenko, L.V. (2015). The future and present of students with disabilities: Psychological aspects. Kyiv: Osnova. 
[3] Sotnikova, K., \& Fedorova, O. (2019). Problem of psychosocial adaptation of people with wade of view in modern Ukraine. Theoretical and Applied Problems of Psychology, 2, 311-320.

[4] Order of the Cabinet of Ministers of Ukraine No. 366-p "On Approval of the National Strategy for Creating a Barrier-Free Space in Ukraine until 2030”. (2021, April). Retrieved from https://zakon.rada.gov.ua/laws/show/366-2021-\%D1\%80\#Text.

[5] Volynets, N.V. (2017). Theoretical analysis of the category "psychological well-being of the personality" in modern psychological science. Theory and Practice of Modern Psychology, 1, 4-17.

[6] Karapetyan, L.V., \& Glotova, G.A. (2018). Structural model of emotional and personal well-being. National Psychological Journal, 11(2), 46-56.

[7] Baturin, N.A., Bashkatov, S.A., \& Gafarova, N.V. (2013). The theoretical model of personal welfare. Bulletin of the South Ural State University. Series "Psychology", 6(4), 4-14.

[8] Voronina, A.V. (2005). The problem of mental health and human wellbeing: Concept overview and experience of level-structure analysis. Siberian Journal of Psychology, 21, 142-147.

[9] Volynets, N.V. (2020). Psychology of personal well-being of the personnel of the State Border Guard Service of Ukraine (Doctoral thesis, G.S. Kostiuk Institute of Psychology of the National Academy of Educational Sciences of Ukraine, Kyiv, Ukraine).

[10] Minuyrova, S.O., \& Zausenko, I.V. (2013). Personal determinants of the teacher's psychological well-being. Pedagogical Education in Russia, 1, 94-101.

[11] Shvalb, Yu.M., Vernik, O.L., Kyrpenko, T.M., Rudomino-Dusiatska, O.V., Vovchyk-Blakytna, O.O., \& Matviienko, O.V. (2018). Personality determinants of ecologically oriented life activity. Kyiv: G.S. Kostiuk Institute of Psychology of the NAES of Ukraine.

[12] Papucha, M.V. (2011). The inner world of man and his formation. Nizhyn: Lysenko M.M.

[13] Volynets, N.V. (2018). Psychological analysis of experiencing psychological well-being. Psychological Prospect Journal, 31, 22-44.

[14] Kolyishko, A.M. (2004). Psychology of self-attitude. Grodno: State University of Grodno.

[15] Tishchenko, L.V. (2012). Phenomenology of self-assignment in psychological science. Scientific Bulletin of V.O. Sukhomlynskyi Mykolaiv National University. Psychological Sciences, 2(9), 230-233.

[16] Stolin, V.V. (1983). Self-awareness of personality. Moscow: Moscow University Press.

[17] Podzhynska, O.O. (2015). Psychological features of students' formation of the value component of personal identity (Candidate thesis, G.S. Kostiuk Institute of Psychology of the National Academy of Educational Sciences of Ukraine, Kyiv, Ukraine).

[18] Shevelenkova, T.D., \& Fesenko, T.P. (2005). Psychological well-being of the individual. Psihologicheskaya Diagnostika, 3, 95-121.

[19] Pantileev, S.R. (2009). Self-attitude research methods. Moscow: Smysl.

[20] Romanova, E.S. (2008). Psychodiagnostics (2nd ed.). St. Petersburg: Piter.

[21] Shvalb, Yu.M., \& Volynets, N.V. (2018). Problems of the methodology of the research of psychological well-being of working person (employee). East European Scientific Journal, 5(33), 57-64.

[22] Budd, J.W., \& Spencer, D.A. (2015). Worker well-being and the importance of work: Bridging the gap. European Journal of Industrial Relations, 21(2), 181-196.

[23] Burke, R.J. (2010). Flow, work satisfactions and psychological well-being at the workplace. The IUP Journal of Soft Skills, $4(1 / 2), 37-48$.

[24] Ryff, C., \& Singer, B. (1998). The contours of positive human health. Psychological Inquiry, 9(1), 1-28.

[25] Gómez-Baya, D., Lucia-Casademunt, A.M., \& Salinas-Pérez, J.A. (2018). Gender differences in psychological well-being and health problems among European health professionals: Analysis of psychological basic needs and job satisfaction. International Journal of Environmental Research and Public Health, 15(7), article number 1474. 


\author{
Людмила Анатоліївна Варава ${ }^{1}$, Олена Володимирівна Кочетова ${ }^{1}$, Віктор Орест $^{2}$ \\ ${ }^{1}$ Маріупольський державний університет \\ 87500, просп. Будівельників, 129а, м. Маріуполь, Україна
}

${ }^{2}$ Національний університет Тайбея

10478, 67 Сек. 3, Східна дорога Мін Шен, м. Тайбей, Тайвань

\title{
Структурні компоненти переживання власного благополуччя осіб з функціональними порушеннями зору
}

\begin{abstract}
Анотація. Проблема переживання власного благополуччя як питання позитивного функціонування особистості в актуалізованих сферах життєдіяльності $€$ актуальним для сучасної психологічної науки та практики. Метою дослідження стало визначення опорних компонентів переживання власного благополуччя осіб 3 функціональними порушеннями зору, рівень виразності яких опосередковує такі переживання. Методологія дослідження грунтується на визначенні провідної ролі саме внутрішніх детермінантів у переживанні власного благополуччя особистістю в умовах функціонального порушення зору. Внаслідок дослідження окреслено структурну модель переживання власного благополуччя осіб з функціональними порушеннями зору, до якої включені такі компоненти, як самоставлення (позитивне або негативне) та особистісні переживання власних можливостей або обмежень в актуалізованих его-ідентичностях. Авторами було визначено, що низький ступінь виразності модальностей самоставлення та негативний окрас особистісних переживань щодо функціональних порушень перешкоджають усвідомленню власної ресурсності особистістю, актуалізації їі можливостей. У процесі емпіричного дослідження з'ясовано, що викривлене самоставлення осіб з функціональними порушеннями зору опосередковується ригідністю Я-образу, його закритістю, а також особистісними переживаннями обмеженості щодо власних функціональних порушень в актуалізованих сферах життєдіяльності. Визначені особливості структурних компонентів переживання власного благополуччя можуть бути використані для розробки та впровадження корекційної програми, спрямованої на формування адекватного рівня самоставлення осіб 3 функціональними порушеннями зору, що й підтверджує практичну цінність наукової роботи
\end{abstract}

Ключові слова: благополуччя особистості, переживання благополуччя, самоставлення, Я-образ, его-ідентичність, особистісні можливості, функціональні та особистісні обмеження 